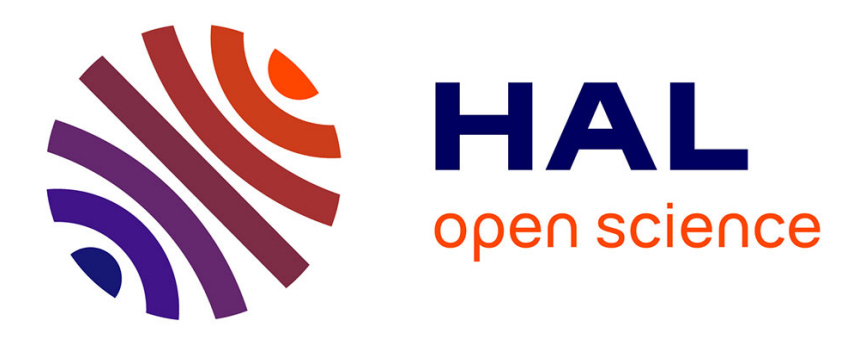

\title{
Pirmat - Interdisciplinary Research Programme on Materials
}

\author{
A. Percheron-Guegan
}

\section{To cite this version:}

A. Percheron-Guegan. Pirmat - Interdisciplinary Research Programme on Materials. Revue de Physique Appliquée, 1986, 21 (11), pp.622-622. 10.1051/rphysap:019860021011062200 . jpa00245481

\section{HAL Id: jpa-00245481 https://hal.science/jpa-00245481}

Submitted on 1 Jan 1986

HAL is a multi-disciplinary open access archive for the deposit and dissemination of scientific research documents, whether they are published or not. The documents may come from teaching and research institutions in France or abroad, or from public or private research centers.
L'archive ouverte pluridisciplinaire HAL, est destinée au dépôt et à la diffusion de documents scientifiques de niveau recherche, publiés ou non, émanant des établissements d'enseignement et de recherche français ou étrangers, des laboratoires publics ou privés. 


\section{PIRMAT}

\section{Interdisciplinary Research Programme on Materials}

\section{Foreword}

In January 1986, the second conference on Materials with Specific Properties was organized in Paris by the MRT and the CNRS which contribute to and support jointly the "Programme Mobilisateur Matériaux $॥$.

In publishing a special issue of the "Revue de Physique Appliquée ", the editorial committee wants to emphasize the interest of the scientific community for the following themes treated during the conference :

- magnetic materials,

- conductors,

- materials for microelectronics,

- materials for communication, sceening and visualization.

This meeting allowed different but complementary groups of interests to get together and discuss, e.g industrialists and basic researchers, manufacturers and utilizers, chemists, physicists and engineers.

It also drew the attention of the participants to innovation, developments, problems not yet solved, the follow up of new tropics and industrial needs.

A. PERCHERON-GUEGAN 